\title{
Probable G-Protein Coupled Receptor 101
}

National Cancer Institute

\section{Source}

National Cancer Institute. Probable G-Protein Coupled Receptor 101. NCI Thesaurus. Code C113542.

Probable G-protein coupled receptor 101 (508 aa, 57 kDa) is encoded by the human GPR101 gene. This protein may play a role in neuronal G protein-coupled receptor signaling pathways. 